\title{
The relationship between auditors' human capital attributes and the assessment of the control environment
}

\author{
Rita Lamboglia ${ }^{1}$ (D) Daniela Mancini ${ }^{2}$
}

Accepted: 11 October 2020 / Published online: 30 October 2020

(c) The Author(s) 2020

\begin{abstract}
The International Standards on Auditing (ISA) consider the understanding of the control environment as a basic phase of an auditor's assessment of internal control. This comprehension influences the nature, timing, extent and, ultimately, the quality of the procedures managed by auditors. Several studies have investigated the determinants and implications of control environment assessment, internal control evaluation, and audit quality. However, very few studies have adopted a human capital perspective and matched the number and type of the control environment elements considered during control environment evaluation with auditors' human capital attributes. Starting from these considerations, the paper examines the relationship between auditors' human capital attributes and the assessment of the control environment. Based on a survey of 100 Italian external auditors, this study reveals that auditors perceive "Communication and enforcement of integrity and ethical values" as a relevant element in undertaking control environment assessments. Moreover, the findings indicate that the type of audit firm (Big Four), the regional context (Northern Italy), and the auditor's degree specialization (accounting, finance and auditing) influence the control environment assessment. This study contributes to the literature by consolidating the use of human capital theory in the auditing domain and presenting new results that help clarify the relationship between human capital attributes and control environment evaluation. We have identified the human capital attributes of auditors that match a control environment evaluation based on all seven elements indicated by ISA 315 .
\end{abstract}

Keywords Control environment assessment · Human capital theory · Audit quality · Big Four $\cdot$ Regional context · Auditors' experience $\cdot$ Auditors' degree specialization

Rita Lamboglia

rita.lamboglia@uniparthenope.it

Daniela Mancini

dmancini@unite.it

1 Department of Business and Economics, Parthenope University, Via Generale Parisi, 13- 80132 Naples, Italy

2 Faculty of Law, University of Teramo, Via R. Balzarini, 1- 64100 Teramo, Italy 


\section{Introduction}

Auditing standards (e.g., ISA 315.74, IFAC 2004b, SAS 109.75. AICPA 2006b), international control frameworks (e.g., CoSo 2013, 2014) and academic studies (Kizirian et al. 2005; Pickerd et al. 2014) highlight the relevance of the control environment as a key component that auditors should be concerned with to further understand the other components of internal control. The control environment consists of the organizational structure and processes, policies, and standards utilized by an entity to maintain control across an organization. Also referred to as the "tone at the top" (Ge and McVay 2005), it is considered to be a key determinant of clients' risk structure, representing the foundation for internal control.

The literature (Haskins 1987; Chow et al. 1987) indicates that control environment assessment is among the most difficult audit tasks but that it is simultaneously very relevant. Auditors must evaluate the "tone at the top" due to its pervasive impact on the client's financial reporting practices and the auditor's reliance on internal controls (Cohen and Hanno 2000).

Examining auditors' "tone at the top" judgement quality and the factors that influence it is important because "tone at the top" judgement deficiencies may compromise audit quality (Schmidt 2014). The auditor's understanding of the control environment affects the nature, timing and extent of audit procedures, and a weak control environment is generally associated with problems involving financial statement errors (Kreutzfeldt and Wallace 1990), fraud (Bell and Carcello 2000) and poor accrual quality (Doyle et al. 2007; Hunton et al. 2011).

Some studies have examined how audit evidence of the control environment impacts audit judgements (e.g., Agoglia et al. 2003; Bernardi 1994; Cohen and Hanno; 2000; Schmidt 2014). For example, some studies (Cohen and Hanno, 2000) have shown that two important elements of the control environment (management control philosophy and governance structure) impact pre-planning and planning judgements and can prove useful in developing work papers and risk assessment models. The way in which auditors consider the control environment influences the judgements that pervade all facets of the auditing process (Beaulieu 2001; Kizirian et al. 2005; Schmidt 2014). Beaulieu (2001) and Kizirian et al. (2005) focus on the management integrity as a key determinant of the client's risk structure, which provides the foundation of internal control. Those authors revealed that management integrity directly impacts the persuasiveness, timing and extent of audit evidence and influences the auditor's assessment of risk.

A highly specialized and professionalized workforce is a distinctive feature of an audit firm in addressing these knowledge-based activities (Morris and Empson, 1998; Von Nordenflycht 2010). Audit firms with high levels of human capital are more skilled in delivering high-quality services (production capabilities) and in attracting and retaining clients (selling capabilities) (Pennings et al. 1998). For a knowledge-based industry such as auditing, human capital appears to represent an important source of innovation and strategic renewal (Bontis 1998; Cheng et al. 2009) and is the main production factor used to provide audit services and to increase audit firms' performance (Bröcheler et al. 2004; Morris and Empson 1998). 
Regulators (e.g., UK Financial Reporting Council 2008; Australian Treasury 2010; Public Company Accounting Oversight Board (PCAOB) 2013; International Auditing and Assurance Standards Board (IAASB) 2014) and the academic literature (e.g., Yan and Xie 2016) related to audit quality show the relevance of human resources and identify auditors' human capital attributes as among the main inputs of the audit process (Cheng et al. 2009; DeFond and Zhang 2014). Studies have revealed that audit quality depends on auditors' integrity and honesty in fulfilling their special responsibility to the public and on auditors' characteristics, skills, professional qualities, competence and independence. While independence arises from reputation and litigation incentives, competency involves the ability to deliver a high audit quality (DeFond and Zhang 2014; Duska 2005).

In accordance with institutional theory (DiMaggio and Powell 1983; Meyer and Rowan 1977) and based on specific evidence reported in several auditing studies (e.g., Arena and Azzone 2007; Arena et al. 2006; Baker et al. 2014; Griffith et al. 2015; Sarens and Abdolmohammadi 2011), it also seems that the socio-economic and legal-regulatory contexts are "key elements in assessing the degree of sensibility towards corporate controls" (Regoliosi and D'Eri 2014: 894) and shape audit firms' audit quality (Wang et al. 2017). Furthermore, recent studies (Bik and Hooghiemstra 2016, 2017; Gómez-Guillamón and Sanchez-Val 2012) have revealed the potential importance of considering the differences of regional contexts, as part of the institutional context, in investigating audit quality. Hope et al. (2008) supported the opinion that the institutional development of each region influences the quality of the audit. Regions with less developed institutions hire smaller audit firms, which are associated with lower quality values than larger audit firms.

Despite the prominence of human capital in the audit industry and the relevance of the assessment of the control environment, our understanding of how auditors' characteristics can influence the evaluation of the control environment is limited. For example, Schmidt (2014) revealed that the assessment of the control environment is based on auditors' mental representations. This study's findings document that once evidence regarding the "tone at the top" is gathered, the cognitive processing of the evidence influences auditors' access to knowledge regarding the "tone at the top", which transfers to control environment assessments and subsequent audit judgements. This research provides evidence showing that examining the quality of auditors' judgement of the control environment and the factors that influence such judgement is important because deficiencies in control environment judgements may compromise the audit quality (Schmidt 2014). Schmidt's (2014) study underscores how auditors develop their "tone at the top" mental representations and shows that these mental representations influence subsequent audit judgements.

To date, however, the literature on the evaluation of the control environment has analysed only some of its elements, and it has not done so in an integrated way. The extant studies have concentrated on the assessment of the following elements, highlighting their roles in the effective development of the audit process: management integrity (Beaulieu 2001; Kizirian et al. 2005; Schmidt 2014), corporate governance factors (Cohen and Hanno 2000; Cohen et al. 2002; Carcello and Neal 2000; Dechow et al. 1995), and management control philosophy (Cohen and Hanno, 2000). In particular, these studies do not analyse which elements in the control environment 
are considered by auditors during their judgements and whether those choices could be related to the auditors' human capital attributes. Moreover, research that focuses on auditor attributes usually considers their impacts on internal control assessment as a whole and does not consider their implications on the control environment as a basic component of the internal control system. Given this research gap, the purpose of this study is to provide an analysis of the relationships between auditors' human capital attributes and control environment assessment.

Specifically, we seek to answer the following questions:

- Which elements of the control environment do external auditors perceive to be relevant in undertaking internal control assessments?

- Is the choice of these elements related to specific external auditors' human capital attributes?

The empirical part of this paper is based on answers to an online questionnaire completed by auditors from Italian audit firms. The data analysis process consisted of two steps. In the first step, we developed a linear multiple regression to determine whether there are positive associations among the four main human capital attributes of auditors (working for a Big Four audit firm, the regional context, the auditors' audit experience, and the auditors' degree specialization) and control environment assessment. In the second step, we used a cluster analysis.

Our main findings are as follows: working for a Big Four firm, the regional context, and the auditors' degree specialization are the human capital attributes that influence control environment assessment.

The remainder of this paper is organized as follows. The following sections develop the hypotheses by discussing the prior research investigating control environment assessment and human capital theory in the audit industry. The "Research methodology" and "Empirical results" sections present the methods and results of the study, respectively. The final section discusses the implications and limitations of this study and presents opportunities for future research.

\section{Prior research and hypothesis development}

Several regulations (e.g., ISA 315; IFAC 2004; AS no.5; PCAOB 2007; SarbanesOxley Act, Section 404) and academic studies (e.g., Kizirian et al. 2005; Cohen and Hanno 2000; Schmidt 2014) consider the control environment to be the basic component of the internal control system and define it as "the tone of an organization"in terms of its governance and management activities and its attitudes and awareness regarding the importance of internal control-and "the control consciousness of its people" (ISA 315: 289; CoSo 1992, 1993).

The importance and the impact of the control environment on auditors' judgement quality are well known and have been demonstrated by several studies. The professional literature suggests that the resulting control environment has a pervasive impact on the overall components of the internal control system (CoSo 1992) because "tone at the top" provides the foundation for all other internal control 
components, and there is a positive association between the "tone at the top" and internal control effectiveness. As illustrated in the International Standard on Auditing 330 (ISA 330), the control environment influences the nature, timing and extent of the resulting audit procedures. In fact, the existence of a satisfactory control environment can help the auditor to rely on internal control and on the audit evidence and allows him or her to conduct audit procedures at an interim date and not at the end of the period (ISA 330: 329; Kizirian et al. 2005). Conversely, weaknesses in the control environment often influence the auditor's assessment of the effectiveness of the other internal control components and his or her assessment of the risks of material misstatement (ISA, 330: 329). Therefore, the results of a control environment assessment are very important because they influence the subsequent audit judgements and can improve the audit quality (Schmidt 2014). The literature has indicated that the control environment has a significant impact on the likelihood of material errors and fraud and on companies' financial reporting quality (e.g., Haskins 1987; Beasley 1996; Bernardi 1994; Quadackers et al. 2014). Further, a common characteristic of major fraud, such as in the cases of Enron and WorldCom, is considered to be a weak control environment (Quadackers et al. 2014).

The relevance of the control environment implies that auditors should understand and evaluate each of its elements to collectively assess their quality as part of the internal control evaluation (ISA Italia no. 315, 2015: 4-5). The International Standard on Auditing (ISA) 315 identifies seven elements of the control environment (ISA 315, 2015: 19), which are as follows:

1. Communication and enforcement of integrity and ethical values These are essential elements that influence the effectiveness of the design, administration and monitoring of controls.

2. Commitment to competence Matters such as management's consideration of the competence levels required for particular jobs and how these levels translate into requisite skills and knowledge.

3. Participation by those charged with governance Attributes of those charged with governance, including

- their independence from management;

- their experience and status;

- the extent of their involvement, the information they receive and the scrutiny of their activities;

- the appropriateness of their actions, including the degree to which difficult questions are raised and pursued with management and their interaction with internal and external auditors.

4. Management's philosophy and operating style Characteristics such as management's

- approach to taking and managing business risks;

- attitudes towards and actions with regard to financial reporting;

- attitudes towards information processing and accounting functions and personnel. 
5. Organizational structure The framework within which an entity's activities for achieving its objectives are planned, executed, controlled, and reviewed.

6. Assignment of authority and responsibility Matters such as how authority and responsibility for operating activities are assigned and how reporting relationships and authorization hierarchies are established.

7. Human resource policies and practices The policies and practices that relate to recruitment, orientation, training, evaluation, counselling, promotion, compensation, and remedial action.

In this paper, control environment assessment is related to the issue covered by ISA Italia 315. This standard specifies that the understanding and assessment of the control environment are based on a collective assessment of seven elements. Therefore, we link control environment assessment to the relevance assigned by auditors to control environment elements, proposing a new measure as a proxy for audit quality. We hypothesize that the more elements that are considered relevant for the evaluation, the more complete the evaluation will be. This hypothesis is based on the definition of "audit quality" according to which the level of audit quality is defined as a degree of compliance with the applicable audit standards (Cook 1987; Jackson et al. 2008; Krishnan and Schauer 2001; Tie 1999).

\subsection{Human capital in the audit industry}

Human capital theory defines human capital as a "resource that is created from the emergence of individuals' knowledge, skills, abilities, and other characteristics" (Ployhart and Moliterno 2011). The research based on this theory analyses the effects of employees' knowledge, skills, abilities and other competences on the capacity of organizations to reach their goals, improve their financial success and achieve sustainable competitive advantages (Barney 1991; Becker 1993; Martin et al. 2013; Unger et al. 2011). The more recent Strategic Human Resource Management (SHRM) literature (Delery 1998; Delery and Roumpi, 2017; Meyer and Xin 2017) emphasizes the strategic role of human resource management in meeting business goals. The fundamental assumption of SHRM studies is that firms adopting a specific strategy require human resource practices that may differ from those required by firms adopting alternative strategies. This difference assumes that there is an important relationship between firm strategy and the human resource practices applied in an organization (Delery and Doty 1996).

Additionally, the auditing literature suggests that human capital is an important determinant in the audit industry (Bontis 1998) and plays a key role in explaining audit firm success and failure (Morris and Empson 1998; Larkin 2000; Sarens and Lamboglia 2014) as well as its performance (Aldhizer et al. 1995; Bröcheler et al. 2004; Cahan and Sun 2015; Chang et al. 2011; Hitt et al. 2001; Samagaio and Rodrigues 2016). These studies suggest that auditors' personal characteristics may serve as a signal of the level of care that will be exercised during the audit process and show that auditors' educational level and work experience can be considered the main attributes of expertise in the auditing profession (Aldhizer et al. 1995; Cahan 
and Sun 2015; Chang et al. 2011; Hitt et al. 2001; Lai and Liu 2018). The literature related to auditor characteristics suggests that auditors play both a monitoring and an information role and that they add value to capital market participants (e.g., Weber and Willenborg 2003; Pittman and Fortin 2004). Highly educated, experienced and committed professionals are a requirement in an industry that provides intellectual and complex services, such as audit firms (Samagaio and Rodrigues 2016), where human resource characteristics are relevant for creating value, producing competitive advantages and enhancing the quality of auditing activities. Moreover, more recent studies connect auditors' human capital attributes with audit quality (Abdolmohammadi et al. 2004; Carcello et al. 1992; Cheng et al. 2009; DeFond and Zhang 2014; McKnight and Wright 2011) and consider these attributes to be among the most important categories "to complete the picture of audit quality" (DeFond and Zhang 2014). The empirical research literature related to the relationship between auditors' characteristics and audit quality is extensive. The studies conducted in this research area reveal that the audit quality is based on whether an auditor works at a Big Four audit firm; the audit team's working relationship with the client company's management; the auditors' educational level, training and knowledge of professional standards; and the audit team's composition and knowledge of the client's business operations and industry (Cahan et al. 2011; Cheng et al. 2009; Corbella et al. 2015; DeFond and Zhang 2014; Hossain et al. 2017).

Based on the extant SHRM studies and the literature on audit quality, this research considers four main auditors' human capital attributes and their relationship to control environment assessment, as described in the following sections. The positive association between auditor's human capital attributes and the control environment assessment concerns the influence of those attributes on a more complete control environment assessment.

\subsection{Big Four audit firms}

The first attribute is based on whether an auditor works at a Big Four audit firm. Over the past three decades, audit markets have been studied extensively. The existence of a dual market structure with a few large audit firms (i.e., the Big Four) and many small audit firms (i.e., the non-Big Four) has strongly influenced this area of research (Bröcheler et al. 2004) because there are important differences between these two groups of firms. First, they provide different services to different clients in different areas (Cheng et al. 2009). Furthermore, there are different influences between them in terms of explaining audit quality (Lawrence et al. 2011; DeFond and Zhang, 2014). In fact, previous studies have demonstrated that audit quality increases with audit firm size because Big Four audit firms have greater reputation concerns and more independence than non-Big Four firms (DeAngelo 1981).

Regarding human capital, auditors who work at Big Four audit firms appear to have different characteristics than those who do not work at these firms. Big Four firms expend considerable resources (through training, the publication of audit manuals) to standardize audit quality and ensure their diversity and professionalism by selecting certain people and specific ways of working (Edgley et al. 2016). 
Investments in human capital and audit technology (Chang et al. 2011; Sirois and Simunic 2011) are higher among the Big Four audit firms; thus, auditors working in these contexts seem to be more competent and can acquire a greater level of expertise and technological knowledge of auditing (O'Keefe et al. 1994). Therefore, we expect the following:

H1: There is a positive association between working for a Big Four firm and the assessment of the control environment.

\subsubsection{Regional context}

The research in the audit field suggests that the location of the audit firm may influence auditors' judgements, auditors' industry specialization and client dependence (Craswell et al. 1995; Reynolds and Francis 2000). More specifically, the findings of several studies (Bik and Hooghiemstra 2016, Bik and Hooghiemstra 2017; GómezGuillamón and Sanchez-Val 2012; Hope et al. 2008; Huang and Li 2009; Wang et al. 2008) have revealed the potential importance of considering the effects of regionspecific differences in the audit industry rather than the national context (Patel and Psaros, 2000; O'Donnell and Prather-Kinsey 2010) because the political and economic development of the region in which a client firm operates affect the firm's choice of auditor. As auditors and auditors-in-charge are members of the society in which they live, their professional judgements and their involvement, including the application of standards and guidelines, are affected by the regional institutional context (Bik and Hooghiemstra 2016, 2017). The research shows that to ensure delivery of a high-quality audit, it is essential to target the methodologies and procedures performed during the various stages of an audit to the cultural dimensions of different regions. The idea that uniform local application of global audit methodologies exists remains illusory (Bik and Hooghiemstra 2016).

Hope et al. (2008) support the view that the institutional development of each region affects the quality of an audit. Regions with less developed institutions hire smaller auditing firms, which are associated with lower quality values, instead of large firms. Moreover, Huang and Li (2009) consider the "geographical hypothesis" in terms of differences in audit practices according to the location of the specific audit office. The authors contend that the audit practices of auditors within the same audit office are highly comparable. They focus on the fact that audit practices differ by the location of the specific audit office because the auditors are industry specialists and auditing work is primarily accomplished at an individual-level office. The results of this study confirm that the geographical location of the specific office where the audit work is performed influences the auditing activities.

Given that Italy is also characterized by "significant differences in the quality and functioning of the regional social- institutional systems" (Daniele and Marani 2011), we use the "geographical context" to consider the location of the office in which auditors work and hypothesize that audit quality is influenced by the economic and institutional development of the audit firm's location (Hope et al. 2008).

In fact, several studies attest that the socio-economic and legal-regulatory context in the Northern Italian regions is more developed than in the Central and Southern regions (ISTAT 2018; Lanzafame 2009; Daniele and Marani 2011) including 
the presence of listed and big companies (De Dominicis et al. 2013), the amount of foreign direct investments (Daniele and Marani 2011), the local development of the financial system and access to credit (La Rocca et al. 2010), the quality of local institutions (Arbolino and Boffardi 2017) and the level of honesty (Del Monte and Papagni 2007).

Therefore, we expect that offices located in the Northern Italian regions, which are characterized by more institutional and economic development, are associated with better audit quality and more complete control environment assessment than offices located in the Southern and Central Italian regions in that a greater number of control environment elements are perceived to be relevant. Therefore, we formulate the following hypothesis:

H2: There is a positive association between the offices located in the regions of Northern Italy and the control environment assessment.

\subsubsection{Working experience in auditing}

A field of studies connects auditors' human capital attributes to their performance in audit firms and highlights that auditor experience, professional proficiency, proactivity, and personality traits cause audit firms to have a high level of performance and contribute to the business success and competitiveness of audit firms. Several behavioural studies have examined the relationship between individual auditors' audit experience and audit judgements (e.g., Alissa et al. 2014; Bonner 1990; Bonner and Lewis 1990; Bröcheler et al. 2004; Cheng et al. 2009; Libby and Frederick 1990; Moeckel 1990; Simnett 1996). These behavioural studies argue that experienced auditors have greater knowledge and more developed memory structures than inexperienced auditors; as a result, experienced auditors make more accurate judgements.

One of the most cited articles, published by Bonner and Lewis (1990), shows that more experienced auditors perform their tasks better because they have more knowledge and ability. Bonner and Lewis (1990) identify at least three types of knowledge (general domain knowledge, subspecialty knowledge, and general business knowledge) and one type of ability (general problem solving ability) as potential determinants of expertise in various auditing tasks.

H3: There is a positive association between more experienced auditors and the control environment assessment.

\subsubsection{Auditors' degree specialization}

The final attribute is related to auditors' degree specialization and pertains to their area of education. Researchers investigating this topic (Cheng et al. 2009; Yan and Xie 2016) argue that auditors' competencies are relevant and must be considered to determine their reliance on auditing activities. Auditors with skills in accounting, finance and auditing are considered to be better able to improve internal control systems, to complete audits and to find relevant solutions based on previous experience. Specific auditors' competencies can also increase the effectiveness of the audit team, improving its activities (American Accounting Association Audit Section Education 
Committee 2003; Blouch et al. 2016). There is some available evidence as to the role that audit education can play in the reduction of the audit expectation gap. The results of such research indicate that respondents who have been exposed to the greatest amount of audit education represent auditors with the necessary skills to scrutinise and evaluate the audit process (Boyle and Canning 2005). The education of future professionals is important because it lays the foundation for the auditor's role (Chaffey et al. 2011). Educational specializations in auditing and accounting may be best suited to facilitate the development of necessary analytical skills by embracing current trends in audit practice and exposing students to complex, realistic, and interactive learning exercises such as cases, role playing, debates, online exercises, and classroom presentations that reflect the challenges of the dynamic environment of auditing in 2000 and beyond (Knechel 2000). Therefore, the following hypothesis can be proposed:

H4: There is a positive association between the specialization of auditors in accounting, finance and auditing and the control environment assessment.

\section{Italian audit setting}

We chose to test our hypotheses in the Italian audit setting for several reasons. First, in the literature, the relationship between auditors' human capital attributes and control environment assessment has essentially been developed considering the U.S. context because of the relevant financial scandals and the enactment of the Sarbanes-Oxley Act (SOX). Although relevant financial scandals and ethical issues (e.g., Parmalat and Cirio) have also characterized the Italian economic environment, there is a lack of literature in this context. Studies that investigate the Italian setting deal with the quality of audits mainly with respect to the rotation of audit firms, adopting a macro perspective and evaluating the tenure and rotation of the auditors (Cameran et al. 2013, 2017, 2018). The literature is still virtually silent regarding the relationship between auditors' human capital attributes and control environment assessment. Starting from this research gap, our study extends the existing literature on this topic by providing new insights from a new context.

Moreover, the Italian audit setting presents features that are similar to those in other countries, in particular the U.S., and others that are different that do not permit the generalization of the results presented in another context. Common features are the domestic audit standard applied based on the ISA, the prohibition on providing non-audit services to listed client firms, the periodic controls on the quality of auditing activity, the degree of auditor independence, and the required minimum technical qualifications mandated by the Stock Exchange Supervisory Commission.

Different features of the Italian audit setting are based on company characteristics and the existence of national legislation. The firms listed on the Italian Stock Exchange are fewer and smaller than the firms in the U.S. and other countries (Veltri and Silvestri 2011). Further, in the Italian market, the ownership concentration has historically been high, and the vast majority of companies are controlled by families, with a governance model based on little separation between family ownership and control. Furthermore, mandatory firm rotation has been required since 1975 
(Cameran et al. 2015; Corbella et al. 2015), and auditors (both audit firms and individual auditors) must be enrolled in a register (Register of Revisori Contabili) whose admission requires a three-year university degree in business administration (or an equivalent degree) and mandatory completion of a three-year training followed by a state examination. Audit firm partners review the overall audit work, are involved in important audit decisions, and are responsible for the final opinion. In addition, to preserve auditor independence, Italian audit firms are prevented from providing many types of non-auditing services.

\section{Research methodology}

\subsection{Data collection and variable measurement}

The empirical part of this paper is based on an online survey given to auditors in Italian audit firms. The questionnaire was available online on the website https:// www.survio.com/it/. Survio is an online survey software tool that permits the formulation of a questionnaire with an unlimited number of questions. Survio provides a free and easy tool for any type of online survey.

The questionnaire was designed and developed in Italian in December and was distributed through LinkedIn from February 2018 until the end of April 2018. A brief private message accompanied the link to the survey, which was sent to 260 professional auditors in Italian audit firms. After clicking on the link, the participants were directed to the survey, which contained brief instructions for completing the survey including definitions of each element of the control environment provided in the ISA 315. Participation was entirely voluntary, and the responses were analysed in aggregate. Before the questionnaire was shared on LinkedIn, it was pretested with six auditors (three auditors working at a Big Four firm and three working at a non-Big Four firm in different roles), which allowed us to refine the questions.

The study received 100 completed questionnaires that could be used in the analysis, representing a response rate of $38 \%$, which is similar to that in other previously published papers concerning the relationship between auditors' human capital attributes and auditing (e.g., Samagaio and Rodrigues 2016; Schelleman and Knechel 2010, Sarens and Lamboglia 2014). The answers were analysed using the webbased Survio analysis tool and Microsoft@ Excel 2016. STATA software version 14 was used for the data processing.

The participants in our research were recruited by LinkedIn and were identified considering the first and second LinkedIn connections of the authors and the participants of two Italian professional auditor groups. By recruiting participants from LinkedIn and reviewing the profile of each participant as it appeared on LinkedIn, we reasonably concluded that they were indeed professionals and experienced as they had reported as their profiles were thoroughly checked before they were granted access to the group. In this way, we built a sample composed of external auditors who had the appropriate knowledge to answer the questions.

The questionnaire included 13 questions consisting of 2 sections. 
Table 1 Auditors' human capital attributes and categories

\begin{tabular}{|c|c|}
\hline Variables & Categories \\
\hline Type of audit firm & $\begin{array}{l}1=\text { Big Four } \\
0=\text { Non-Big Four }\end{array}$ \\
\hline Regional context & $\begin{array}{l}1=\text { Northern Italy } \\
2=\text { Central Italy } \\
3=\text { Southern Italy }\end{array}$ \\
\hline Position in the audit firm & $\begin{array}{l}1=\text { Manager } \\
2=\text { Partner (associate) } \\
3=\text { Senior staff } \\
4=\text { Staff } \\
5=\text { Intern }\end{array}$ \\
\hline $\begin{array}{l}\text { Number of years of work experience in } \\
\text { auditing }\end{array}$ & $\begin{array}{l}1=0-6 \text { months } \\
2=6 \text { months }-2 \text { years } \\
3=2-5 \text { years } \\
4=5-10 \text { years } \\
5=\text { More than } 10 \text { years }\end{array}$ \\
\hline Level of education & $\begin{array}{l}1=\text { Master's degree } \\
2=\text { Bachelor's degree } \\
3=\text { Post-graduate level }\end{array}$ \\
\hline Degree specialization & $\begin{array}{l}1=\text { Accounting }, \\
\text { finance and auditing } \\
2=\text { Management } \\
3=\text { Marketing } \\
4=\text { Other }\end{array}$ \\
\hline
\end{tabular}

In the first section, we collected information regarding the auditors' human capital attributes based on the following variables:

1. Type of audit firm (Question 1)

2. Regional context of the office in which the auditor works (Question 2)

3. Position in the company (Question 3)

4. Number of years of work experience in auditing (Question 4)

5. Level of education (Question 5)

6. Degree specialization (Question 6)

The variables listed above were evaluated as summarized in Table 1.

In the second section of the questionnaire, we collected information regarding how the auditors assess the control environment. To analyse this aspect, we considered the indications in the ISA 315. This standard specifies that the auditor shall obtain a comprehensive understanding and evaluation of all seven control environment elements to provide an appropriate assessment.

To evaluate how the auditors assess the control environment, the respondents were asked to indicate the level of relevance that they attribute to the seven elements indicated in the ISA 315 when they perform a control environment evaluation; in other words, which of the seven control environment elements they perceive to be relevant in undertaking an internal control assessment. The respondents reported their answer for each element using a Likert scale composed 
of the following five levels: strongly disagree, disagree, neither agree nor disagree, agree, and strongly agree.

We have hypothesized that the more control environment elements indicated in the ISA 315 that are perceived to be relevant for the evaluation, the higher the quality of the evaluation will be. This hypothesis is grounded in the definition of audit quality, according to which the level of audit quality is defined as the degree of compliance with the applicable auditing standards (Cook 1987; Jackson et al. 2008; Krishnan and Schauer 2001; Tie 1999). Therefore, the positive association between the four auditors' human capital attributes and control environment assessment examines the influence of these attributes on a more effective control environment assessment.

\subsection{Data analysis}

The data analysis was performed in two steps.

In the first step, we developed a linear multiple regression similar to that proposed in other studies (Hossain et al. 2017) to determine whether there is a positive association between the four human capital attributes of auditors and control environment assessment.

In the second step, we used a cluster analysis to overcome the limitations of linear multiple regression, allowing us to analyse each of the four characteristics of auditors individually. The cluster analysis also permits an assessment of the association between the auditors' human capital attributes and control environment assessment. The cluster composition is analysed with respect to the following auditor attributes: belonging to a Big Firm audit firm, the regional context in which the auditor office is located, position in the audit firm, number of years of work experience in auditing, level of education, and auditor's degree specialization.

\subsection{Regression model}

We used a multiple linear regression to test the previously indicated research hypotheses.

Our dependent variables are the seven elements of the control environment indicated in the ISA 315.

As auditor-specific characteristics, we considered the probability of working for a Big Four firm (BIG4), the regional context of the office in which the auditors' work (AREA), the auditors' experience level (EXP), and their degree specialization (EDU).

$$
\mathrm{CE}=\beta 0+\beta 1(\mathrm{BIG} 4)+\beta 2(\mathrm{AREA})+\beta 3(\mathrm{EXP})+\beta 4(\mathrm{EDU})+\varepsilon
$$

Our dependent variable, i.e., the control environment (CE), is based on an alternative measure of the control environment.

The independent variables are described as follows:

BIG4 is a dummy variable revealing the probability of working for a Big Four firm, and AREA indicates the regional context of the office in which the auditor 
works (Northern, Central, or Southern Italy). In our model, Southern Italy is the reference modality.

EXP is a dummy variable indicating the number of years of experience (less than 10 years or equal to/more than 10 years). EDU indicates the type of degree obtained (management, marketing or accounting, finance and auditing). In our model, a business administration finance and control degree is the reference modality.

\subsection{Cluster analysis}

To overcome the limitations of linear regression, which allows us to identify only one relationship at a time between each element of the control environment and the auditors' human capital attributes, we also performed a cluster analysis. This methodology allows the simultaneous consideration of all task and control factors and characteristics of the auditors.

Cluster analysis is a useful classification technique that aims to group observations into clusters; observations within the same cluster are similar, and observations belonging to different clusters are quite dissimilar. Segmenting a phenomenon refers to dividing its observations into separate sub-sets that are homogeneous but relatively different from other sub-sets with respect to a given set of characteristics (Mazzocchi 2008).

In our paper, a cluster analysis is first applied to the seven control environment elements considered in the analysis, allowing us to classify auditors into homogeneous groups (clusters) to maximize homogeneity (i.e., minimize the variance) within the clusters and maximize heterogeneity (i.e., maximize the variance) between the clusters.

The distance measure used in this analysis is the Euclidian distance measure, and the algorithm used to obtain the classification is the Ward measure. ${ }^{1}$

The optimal number of clusters was chosen by inspecting the dendrogram (Fig. 1). The individual observations (the 100 questionnaire respondents) are listed on the horizontal axis and joined by lines whose widths vary according to the distance at which the nesting occurs.

\section{Empirical results}

\subsection{Descriptive statistics}

Table 2 shows the descriptive statistics of the auditor profile characteristics.

\footnotetext{
1 This measure is the most widely used Ward method, and it is slightly more complex and computationally demanding. First, the sum of the squared distances is computed within each cluster by considering all distances between the observations within the same cluster. Then, the algorithm proceeds by choosing the aggregation between two clusters that generates the smallest increase in the total sum of the squared distances. This method is computationally intensive because at each step, and all sums of the squared distances must be computed along with all potential increases in the total sum of the squared distances of each possible aggregation of clusters.
} 


\section{Dendrogram}

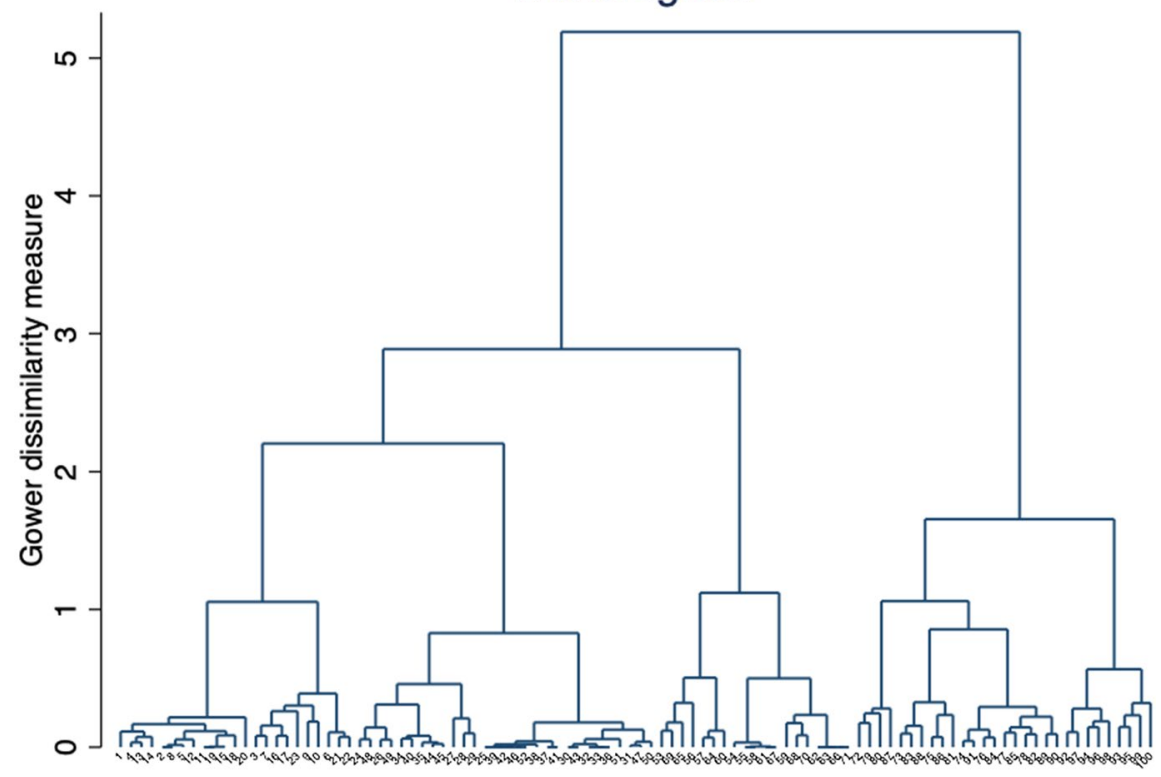

Fig. 1 Dendrogram of the seven factors analysed

Table 2 Auditors' human capital attributes

\begin{tabular}{|c|c|c|c|}
\hline \multicolumn{2}{|l|}{ Panel A: Type of audit firm } & \multicolumn{2}{|c|}{ Panel B: Regional context of the office } \\
\hline Non-big four & $16 \%$ & Northern Italy & $31 \%$ \\
\hline KPMG & $38 \%$ & Southern Italy & $26 \%$ \\
\hline PWC & $16 \%$ & Central Italy & $43 \%$ \\
\hline DELOITTE & $16 \%$ & & \\
\hline $\mathrm{E} \& \mathrm{Y}$ & $14 \%$ & & \\
\hline Panel C: Position in the audit firm & & Panel D: Level of education & \\
\hline Intern & $13 \%$ & Bachelor's degree & $11 \%$ \\
\hline Staff & $31 \%$ & Master's degree & $61 \%$ \\
\hline Senior staff & $29 \%$ & Post-graduate level & $28 \%$ \\
\hline Manager & $17 \%$ & & \\
\hline Partner/Associate & $10 \%$ & & \\
\hline Panel E: Degree specialization & & $\begin{array}{l}\text { Panel F: Number of years of work } \\
\text { experience in auditing }\end{array}$ & \\
\hline Accounting, finance and auditing & $66 \%$ & 0 to 6 months & $12 \%$ \\
\hline General business/Management & $32 \%$ & 6 months to 2 years & $28 \%$ \\
\hline Language, literature, history and psychology & $0 \%$ & 2 years to 10 years & $34 \%$ \\
\hline Engineering & $2 \%$ & 10 years or more & $11 \%$ \\
\hline
\end{tabular}


Table 3 Percentage frequencies of the control environment elements

\begin{tabular}{lrrrrrrr}
\hline & P1 & P2 & P3 & P4 & P5 & P6 & P7 \\
\hline Strongly disagree/disagree & $0 \%$ & $8 \%$ & $12 \%$ & $13 \%$ & $69 \%$ & $7 \%$ & $8 \%$ \\
Neither agree nor disagree & $12 \%$ & $11 \%$ & $21 \%$ & $17 \%$ & $13 \%$ & $37 \%$ & $16 \%$ \\
Agree/strongly agree & $88 \%$ & $81 \%$ & $67 \%$ & $70 \%$ & $18 \%$ & $56 \%$ & $76 \%$ \\
\hline
\end{tabular}

Panel A shows that most respondents work for a Big Four firm (84\%). Panel B shows that most respondents work at offices located in Central Italy (43\%). Panel $\mathrm{C}$ shows that $31 \%$ of the respondents work as staff, $29 \%$ of the respondents work as senior staff, $17 \%$ of the respondents work as managers, $13 \%$ of the respondents work as interns, and $10 \%$ of the respondents work as partners/associates. Panel D shows that most of the responding auditors hold a Master's degree (61\%). Panel E shows that the three most common educational specializations are general accounting, finance and auditing. Panel F shows that $34 \%$ of the respondents have between 2 and 10 years of experience in auditing, 28\% of the respondents have between 6 months and 2 years of experience, $12 \%$ of the respondents have between 0 and 6 months of experience, and $11 \%$ of the respondents have 10 or more years of experience.

To facilitate the analysis of the data and interpretation of the results, we summarized all the variables included in the dataset (regarding the environmental control) into smaller variables using correspondence analysis. This method was useful because it helped us measure certain unobservable or latent characteristics of the environmental control through a set of measurable variables. Correspondence analysis is particularly useful when the variables have many categories. In our case, the variables regarding environmental control included in the dataset included 5 categories (strongly disagree, disagree, neither agree nor disagree, agree, and strongly agree). We applied a measure of distance, and the resulting matrix is similar to a covariance matrix, which allowed us to apply a method for reducing the number of dimensions.

To capture all seven elements of the control environment in a synthetic manner as indicated in the ISA 315, we use the following coding:

P1: Communication and enforcement of integrity and ethical values

P2: Commitment to competence

P3: Participation by those charged with governance

P4: Management's philosophy and operating style

P5: Organizational structure

P6: Assignment of authority and responsibility

P7: Human resource policies and practices.

We synthesized each extracted dimension into three categories: strongly disagree or disagree, neither agree or disagree, and agree and strongly agree.

Table 3 shows the percentage frequencies of the control environment elements in relation to the 3 levels of evaluation used.

The percentage of auditors who agree/strongly agree with the relevance of the elements (Table 3 ) reveals that the elements that are most commonly perceived to 
Table 4 OLS regression results

\begin{tabular}{|c|c|c|c|c|c|c|c|}
\hline & $\mathrm{P} 1$ & $\mathrm{P} 2$ & $\mathrm{P} 3$ & $\mathrm{P} 4$ & P5 & P6 & P7 \\
\hline \multicolumn{8}{|c|}{ Big Four (ref. No) } \\
\hline Yes & $\begin{array}{l}0.108 \\
(0.902)\end{array}$ & $\begin{array}{l}0.100 \\
(0.062)\end{array}$ & $\begin{array}{l}0.186 \\
(0.066)^{* * * *}\end{array}$ & $\begin{array}{l}0.033 \\
(0.076)\end{array}$ & $\begin{array}{l}0.024 \\
(0.098)\end{array}$ & $\begin{array}{l}-0.026 \\
(0.076)\end{array}$ & $\begin{array}{l}0.041 \\
(0.073)\end{array}$ \\
\hline \multicolumn{8}{|c|}{ Area (ref. Southern) } \\
\hline Northern & $\begin{array}{l}2.671 \\
(1.135)^{* *}\end{array}$ & $\begin{array}{l}0.133 \\
(0.063)^{* *}\end{array}$ & $\begin{array}{l}0.112 \\
(0.067)^{*}\end{array}$ & $\begin{array}{l}0.224 \\
(0.077)^{* * * *}\end{array}$ & $\begin{array}{l}0.036 \\
(0.099)\end{array}$ & $\begin{array}{l}0.225 \\
(0.077)^{* * *}\end{array}$ & $\begin{array}{l}0.088 \\
(0.074)\end{array}$ \\
\hline Central & $\begin{array}{l}1.617 \\
(0.737)^{* *}\end{array}$ & $\begin{array}{l}0.100 \\
(0.061)\end{array}$ & $\begin{array}{l}0.058 \\
(0.065)\end{array}$ & $\begin{array}{l}0.160 \\
(0.075)^{* *}\end{array}$ & $\begin{array}{l}0.032 \\
(0.096)\end{array}$ & $\begin{array}{l}0.234 \\
(0.075)^{* * *}\end{array}$ & $\begin{array}{l}0.033 \\
(0.071)\end{array}$ \\
\hline \multicolumn{8}{|c|}{ Field of study (ref. finance administration and control) } \\
\hline Management & $\begin{array}{l}-0.343 \\
(0.714)\end{array}$ & $\begin{array}{l}-0.105 \\
(0.051)^{* *}\end{array}$ & $\begin{array}{l}-0.022 \\
(0.054)\end{array}$ & $\begin{array}{l}-0.095 \\
(0.062)\end{array}$ & $\begin{array}{l}-0.013 \\
(0.080)\end{array}$ & $\begin{array}{l}-0.089 \\
(0.062)\end{array}$ & $\begin{array}{l}-0.101 \\
(0.059)^{*}\end{array}$ \\
\hline Marketing & & $\begin{array}{l}-0.164 \\
(0.171)\end{array}$ & $\begin{array}{l}-0.318 \\
(0.181)^{*}\end{array}$ & $\begin{array}{l}-0.212 \\
(0.209)\end{array}$ & $\begin{array}{l}0.017 \\
(0.269)\end{array}$ & $\begin{array}{l}0.113 \\
(0.208)\end{array}$ & $\begin{array}{l}-0.156 \\
(0.199)\end{array}$ \\
\hline \multicolumn{8}{|c|}{ Years (ref. less than 10) } \\
\hline \multirow[t]{2}{*}{$\begin{array}{r}\text { More than } \\
10 \text { years }\end{array}$} & 1.255 & 0.004 & 0.083 & 0.052 & 0.036 & 0.100 & -0.004 \\
\hline & $(1.167)$ & $(0.069)$ & $(0.074)$ & $(0.085)$ & $(0.109)$ & $(0.084)$ & $(0.081)$ \\
\hline Constant & $\begin{array}{l}0.722 \\
(0.555)\end{array}$ & $\begin{array}{l}0.753 \\
(0.053)^{* * *}\end{array}$ & $\begin{array}{l}0.617 \\
(0.056)^{* * *}\end{array}$ & $\begin{array}{l}0.653 \\
(0.065)^{* * *}\end{array}$ & $\begin{array}{l}0.247 \\
(0.083)^{* * * *}\end{array}$ & $\begin{array}{l}0.621 \\
(0.064) * * *\end{array}$ & $\begin{array}{l}0.790 \\
(0.062)^{* * * *}\end{array}$ \\
\hline$N$ & 98 & 100 & 100 & 100 & 100 & 100 & 100 \\
\hline $\mathrm{R} 2$ & & 0.040 & 0.07 & 0.04 & 0.06 & 0.08 & 0.02 \\
\hline
\end{tabular}

$* p<0.1 ; * * p<0.05 ; * * * p<0.01$

be relevant in undertaking internal control assessments are $P 1$ (Communication and enforcement of integrity and ethical values),

P2 (Commitment to competence) and P7 (Human resource policies and practices).

The results show that the respondents perceived P1 (communication and enforcement of integrity and ethical values) to be relevant in undertaking their assessments. Regarding this element, no respondents disagreed with its relevance, and $88 \%$ of the respondents indicated that they agreed or strongly agreed. The other elements perceived to be relevant for the assessment of the control environment include P2 (commitment to competence), with which $81 \%$ of the respondents agreed/strongly agreed; P7 (human resource policies and practices), with which $76 \%$ of the respondents agreed/strongly agreed; and P4 (management's philosophy and operating style), with which $70 \%$ of the respondents agreed/strongly agreed. P5 (organizational structure) is the element with the highest percentage of auditors who disagreed or strongly disagreed with (69\%). This last result seems to be in line with the revised version of the ISA 315 (2019), in which the organizational structure is no longer described as a control environment element but is considered part of obtaining an understanding of the entity. 
Table 5 Dimensions of each cluster

\begin{tabular}{ll}
\hline Cluster & \% of auditors \\
\hline 1 & 23 \\
2 & 29 \\
3 & 19 \\
4 & 29 \\
\hline
\end{tabular}

\subsection{Hypothesis testing}

Table 4 reports the Ordinary Least Squares (OLS) regression results of the auditors' human capital attributes affecting control environment assessment.

In the first regression, the communication and enforcement of integrity and ethical values element was significantly and positively associated with AREA $(\mathrm{p}<0.05)$.

In the second regression, the commitment to competence element was significantly and positively associated with AREA $(\mathrm{p}<0.05)$; moreover, this element was significantly and negatively associated with EDU $(\mathrm{p}<0.05)$ as follows: the respondents with a management degree attached lower importance to this element than did those with a business administration finance and control degree.

In the third regression, the participation by those charged with governance element was significantly and positively associated with BIG4 $(\mathrm{p}<0.01)$ and AREA $(p<0.10)$; moreover, this element was significantly and negatively associated with EDU $(\mathrm{p}<0.10)$ as follows: the respondents with a marketing degree attached lower importance to this pillar than did those with a business administration finance and control degree.

In the fourth regression, the management's philosophy and operating style element was significantly and positively associated with AREA $(\mathrm{p}<0.05)$.

In the fifth regression, the organizational structure element was not associated with any human attributes.

In the sixth regression, the assignment of authority and responsibility element was significantly and positively associated with AREA $(\mathrm{p}<0.01)$.

In the seventh regression, the human resource policies and practices element was significantly and positively associated with EDU $(\mathrm{p}<0.10)$ as follows: the respondents with a management degree attached lower importance to this pillar than did those with a business administration finance and control degree.

These results support $\mathrm{H} 1, \mathrm{H} 2$ and $\mathrm{H} 4$. The findings provide evidence that the control environment evaluation is a function of the following auditors' human capital attributes: AREA, EDU, and BIG4. However, the variable that has the greatest influence on the control environment evaluation is the office where the auditor works. This result suggests that the regional context of the office is a highly relevant component in the control environment evaluation.

The results do not support $\mathrm{H} 2$ regarding the influence of the auditors' audit experience on control environment assessment, suggesting that the number of years of work experience in auditing does not influence control environment assessment. 
Table 6 Variables specific to each cluster

\begin{tabular}{llll}
\hline Cluster 1 & Cluster 2 & Cluster 3 & Cluster 4 \\
\hline P1 & P1 & P1 & P1 \\
P2 & P2 & P2 & - \\
P3 & P3 & P3 & - \\
P4 & P4 & P4 & - \\
- & - & P5 & - \\
- & P6 & P6 & - \\
P7 & P7 & P7 & - \\
\hline
\end{tabular}

\subsection{Cluster analysis}

Based on the results of the dendrogram (Fig. 1), we considered 4 clusters of auditors. The dimensions of each cluster are presented in Table 5.

Table 5 shows that the largest clusters are numbers 2 and 4.

Table 6 displays the variables that characterize each cluster.

Each group is characterized by a positive evaluation (agree and strongly agree) of the control environment elements expressed by the auditors.

Table 6 shows that the auditors in cluster 3 agreed or strongly agreed with all control environment elements. In contrast, the auditors in cluster 4 agreed or strongly agreed with only one of the variables (P1, communication and enforcement of integrity and ethical values) of the control environment.

Furthermore, there are two intermediate clusters, i.e., cluster 1 and cluster 2. The auditors in the first cluster agreed with all the elements except for P5 (organizational structure) and P6 (assignment of authority and responsibility). The auditors in the second cluster agreed with all the elements except for P5 (organizational structure).

In the final step of our cluster analysis, we identified the human capital attributes included in each previously described cluster (Table 7).

Table 7 shows that the four clusters have different compositions.

Cluster 3, which, as indicated in Table 6, considers all control variables to be relevant, is characterized by auditors with the following characteristics: auditors who work at two different Big Four firms (Deloitte and PWC) or do not work for a Big Four audit firm; auditors who are partners, staff or interns; auditors who hold a Master's degree in accounting, finance or auditing; auditors who work at an office located in central Italy; and auditors with 0-6 months, 2-5 years, or over 5 years of work experience in auditing.

In contrast, cluster 4 , which considers only one control environment element to be relevant, is characterized by auditors with the following characteristics: auditors who work for only one Big Four audit firm (PWC) or do not work for a Big Four firm; auditors who serve as managers, staff or interns; auditors who hold a three-year degree in management; auditors who work at an office located in Southern Italy; and auditors with 0-6 months or 5-10 years of work experience in auditing. 
Table 7 Auditors' human capital attributes in the clusters

\begin{tabular}{|c|c|c|c|c|}
\hline & Cluster 1 & Cluster 2 & Cluster 3 & Cluster 4 \\
\hline Type of audit firm & $\begin{array}{l}\text { Non-Big Four } \\
\text { E\&Y }\end{array}$ & $\begin{array}{l}\text { E\&Y } \\
\text { KPMG }\end{array}$ & $\begin{array}{l}\text { Non-Big Four } \\
\text { Deloitte } \\
\text { PWC }\end{array}$ & $\begin{array}{l}\text { PWC } \\
\text { Non-Big Four }\end{array}$ \\
\hline \multirow[t]{5}{*}{ Position in the company } & Manager & & & Manager \\
\hline & & Partner & Partner & Partner \\
\hline & Senior staff & & & \\
\hline & & Staff & Staff & \\
\hline & & & Intern & Intern \\
\hline \multirow{5}{*}{$\begin{array}{l}\text { Number of years of } \\
\text { work experience in } \\
\text { auditing }\end{array}$} & & & $0-6$ months & $0-6$ months \\
\hline & & 6 months -2 years & & \\
\hline & $2-5$ years & & $2-5$ years & \\
\hline & $5-10$ years & & & $5-10$ years \\
\hline & & $>10$ years & $>10$ years & \\
\hline \multirow[t]{3}{*}{ Level of education } & Master's degree & Master's degree & Master's degree & \\
\hline & & Bachelor's degree & & Bachelor's degree \\
\hline & Post-graduate level & & & Post-graduate level \\
\hline \multirow[t]{2}{*}{ Degree specialization } & $\begin{array}{l}\text { Accounting, } \\
\text { finance and } \\
\text { auditing }\end{array}$ & & $\begin{array}{l}\text { Accounting, } \\
\text { finance and } \\
\text { auditing }\end{array}$ & \\
\hline & & Marketing & & Management \\
\hline \multirow{3}{*}{$\begin{array}{l}\text { Regional context of the } \\
\text { office }\end{array}$} & Northern & Northern & & \\
\hline & & Central & Central & \\
\hline & & & & Southern \\
\hline
\end{tabular}

Clusters 1 and 2, which include auditors who consider almost all control environment elements to be relevant, have different compositions from those of the other two clusters.

In particular, cluster 1 includes auditors with the following characteristics: auditors who do not work for a Big Four audit firm or work for Ernst \& Young; auditors who serve as managers or senior staff; auditors with 2-5 years or 5-10 years of experience in auditing; auditors who hold a Master's degree or have a post-graduate education; auditors specialized in accounting, finance or auditing; and auditors who work at an office located in Northern Italy.

Cluster 2 includes auditors with the following characteristics: auditors who work for only two Big Four audit firms (Ernst \& Young and KPMG); auditors who serve as partners or staff; auditors with 6 months-2 years or over 10 years of experience in auditing; auditors who hold a Master's degree or a bachelor's degree; auditors with specializations in marketing; and auditors who work at offices located in Northern or Central Italy. 


\section{Conclusions, limitations and future research}

Based on the SHRM studies and the literature on audit quality, this paper provides an analysis of the relationship between auditors' human capital attributes and control environment assessment. Specifically, it identifies the control environment elements that external auditors perceive to be relevant in their judgements and whether the choice of these elements is related to specific auditors' human capital attributes. The empirical part of the research is based on answers to online questionnaires completed by 100 auditors of Italian audit firms. The respondents were asked to indicate the level of relevance that they attribute to the seven elements indicated in the ISA 315 when they perform a control environment evaluation.

The findings show that the auditors do not consider all elements proposed by the ISA 315 to be relevant when performing an evaluation of the control environment. The percentage of auditors who agreed/strongly agreed with the relevance of the elements revealed that the elements that are most commonly perceived to be relevant in undertaking internal control assessments are "Communication and enforcement of integrity and ethical values", "Commitment to competence" and "Human resource policies and practices".

The OLS regression provided evidence that the control environment evaluation is related to the following auditors' human capital attributes: working for a Big Four firm, the regional context and the auditors' degree specialization. However, the variable that has the greatest influence on the control environment evaluation is the office location in which the auditors work. Our results do not support the third hypothesis regarding the auditors' audit experience, suggesting that the number of years of work experience in auditing does not influence control environment assessment. Moreover, the results of the cluster analysis showed that the cluster that considers all seven control environment elements to be relevant during its evaluation is characterized by auditors with the following characteristics: auditors who work for two different Big Four firms (Deloitte and PWC) or do not work for a Big Four audit firm; auditors who are partners, staff or interns; auditors who hold a Master's degree in accounting, finance or auditing; auditors who work at an office located in Central Italy; and auditors with 0-6 months, 2-5 years, or over 5 years of work experience in auditing. This result allows us to confirm that different characteristics of audit team members influence audit quality (Hossain et al. 2017) and obtain dissimilar control environment assessments.

Our findings could be related to those of Hossain et al. (2017) considering, however, that we used the number of control environment elements perceived to be relevant during its evaluation, while they used audit opinion and discretionary accruals as measures of audit quality proxy. In general, both studies confirm that auditor characteristics influence audit quality.

Similar to the findings of Hossain, audit quality was not related to other expertise or degree specialization of the audit team member other than accounting or auditing, even if we adopted a different audit quality measure. A possible explanation could be the attention of Italian Universities to the provision of academic education programmes in business administration, which allow students to gain skills 
and advanced expertise in accounting practices and auditing and, in this way, to cultivate qualified specialists. These education programmes together with training programmes and state examinations are considered mandatory requirements to be enrolled in the Register of Revisori Contabili.

In contrast to the findings of Hossain et al. (2017), we did not find a significant association between the length of work experience in auditing and audit quality, even if, as highlighted above, the institutional context for access to the auditing profession was the same. A possible explanation could be that we used different measures to capture audit quality and auditors' seniority (number of years of work experience in auditing instead of the number of senior auditors). Our finding reinforces Hossain et al.'s results, which supports our assertion that the number of years of work experience does not ensure audit quality; however, it is necessary to consider the number of senior auditors in the audit team.

Furthermore, unlike Hossain et al. (2017), we showed a positive association between working for a Big Four firm and audit quality. We can justify our result considering the institutional aspects of the Italian context, mainly with regard to the relevant financial scandals of listed companies (e.g., Parmalat, Monte dei Paschi, Cirio). In response to those scandals, the audit profession has become more developed in Italy, and Big Four firms in particular have had to model their audit practices on the strong financial market legislation (Law no. 262/2005) and mandatory audit profession requirements, paying more attention to control environment elements and the ethical issues of their clients. Thus, the measure of audit quality based on the number of control environment elements permits capturing the relationship between Big Four firms (non-Big Four Firms) and audit quality.

In addition to the above results and explanations, Italy is also characterized by regional heterogeneity in terms of institutions and economic activities, which help explain the result of the second hypothesis. Our finding confirms that offices located in more developed regions, such as Northern Italy, may influence higher audit quality. The auditors and auditors-in-charge located in a given workplace are members of the society in which they live, and their professional judgements and their involvement, including the application of standards and guidelines, are affected by the regional institutional context.

This study makes theoretical and practical contributions for several different groups.

For researchers, it contributes to the extant literature that seeks to better understand the relationship between auditors' human capital attributes and audit quality by adding further empirical evidence to the existing studies regarding control environment assessment. We have identified auditors' human capital attributes that match the control environment evaluation based on all seven elements indicated by the ISA 315. In doing so, different from the previous studies, we did not consider the internal control system as a whole but rather focused on the control environment as its basic component examined in an integrated way. Moreover, we tested the effectiveness of a different measure as proxy of audit quality in interpreting the relevance of the type of audit firm, the regional context and the auditors' degree specialization.

The study also provides insights on the application of the ISA 315 in the Italian setting, contributing to the professional and academic literature with analysis of the 
seven control environment elements that auditors consider to be most relevant during its assessment. Our findings reinforce the statement in Committee of Sponsoring Organizations of the Treadway Commission (COSO) (1992), asserting that the enforcement of ethical values and communication within an organization are key factors in establishing an effective control environment. The results of this study support the recommendations of CoSo, which calls for auditors to assess the presence in companies of high values and their ability to promote honesty and integrity among their employees on a day-to-day basis and effectively communicate such values. The findings also support the academic literature, which corroborates the notion that a strong ethical climate is a critically important element in a firm's control environment (e.g., Hunton et al. 2011; Pickerd et al. 2014). Moreover, in addition to the academic research that has provided empirical analysis mainly considering only this control environment element, our study examines all seven control environment elements in an integrated way.

Second, this study offers implications for practitioners, especially auditors-incharge who must assess the conditions required to succeed in their audit strategy. According to the SHRM studies, our results provide indications for the management of human resources' knowledge, skills, abilities and other competences that are consistent with their audit strategy. If an audit firm adopts an audit strategy based on a comprehensive control environment assessment, it should require its auditors to have specific human capital attributes such as those included in cluster P3. In fact, the ability of human resources to conduct a comprehensive control environment assessment could enhance the nature, timing and extent of the resulting audit procedures as suggested in the ISA 330.

Third, the study also offers implications for the audited companies to choose their auditors. Presenting evidence of the correspondence between the control environment elements considering the evaluation and the auditors' human capital attributes, this research provides suggestions for the selection of audit firms according to the control environment elements that firms want to be assessed and to obtain high quality assurance.

Compared with the prior literature our study offers advantages as well as certain limitations.

A limitation of this study is the number of observations because these data originated from only one country. However, the number of observations we considered in this paper is similar to the number used in other previously published papers (e.g., Samagaio and Rodrigues 2016; Schelleman and Knechel 2010). Moreover, the use of Big Four firm data partially alleviates concerns arising from employing data from a single country because these firms have very well-developed international networks and internal working rules that guide and standardize their activities at the international level. As noted above, certain features of the Italian context might not be present in other audit markets. To the extent that audit quality is influenced by these features, our results cannot be generalized to countries with different characteristics. Therefore, our findings might be of relevance for several countries that share similar characteristics with the Italian auditing setting.

Another significant limitation concerns data collection regarding the control environment as dependent variable throughout the questionnaire and the inferences 
that can be drawn from auditors' responses. We asked respondents to indicate their perception on the level of relevance that they attribute to the seven elements of the ISA 315 when they perform the control environment evaluation, without specifying any aspects related to the context as the client/engagement. For example, the size of the client could be an important factor in determining which of the control environments elements might be perceived as relevant. Moreover, we recorded the relevance respondents attribute to each element of the control environment when they perform an evaluation of this component of the internal control system, which is not the same as asking whether they would consider or evaluate each element for each client. For example, an auditor might assess a control environment element although he or she perceived it to be less relevant. Furthermore, even if the ISA 315 states that auditors must obtain an understanding of each control environment component and the strength of its seven relevant elements, the document does not mandate that all elements must be evaluated. The ISA 315 states that those elements might have a pervasive or limited effect (A72, A73) depending on the context in assessing the risks of material misstatement.

Finally, although in the questionnaire we have provided some information to define each control environment element, some of the survey's responses may have been subject to bias; therefore, the inferences on audit quality and completeness of a control environment assessment might be questionable, such as responses regarding the relevance of the organizational structure. This concept is broad and overlaps with obtaining an understanding of the entity and its environment; in fact, in the new version of the ISA 315 (Revised 2019), it is no longer listed as a control environment element but is instead referred to as part of obtaining an understanding of the entity.

Our study is the first attempt to empirically study auditors' human capital attributes and their control environment assessments using data from Italy, and it extends the existing literature by providing insights from a new context. Further research could continue exploring these relationships by using larger and international samples and including other auditor human capital attributes. In addition, future research could identify audit quality measures that more directly coincide with control environment assessments with reference to a specific context and examine their associations with the auditors' human capital attributes. A set of new variables may be considered for the development of the research in addition to the factors used when measuring audit quality.

Funding Open access funding provided by Università Parthenope di Napoli within the CRUI-CARE Agreement.

Open Access This article is licensed under a Creative Commons Attribution 4.0 International License, which permits use, sharing, adaptation, distribution and reproduction in any medium or format, as long as you give appropriate credit to the original author(s) and the source, provide a link to the Creative Commons licence, and indicate if changes were made. The images or other third party material in this article are included in the article's Creative Commons licence, unless indicated otherwise in a credit line to the material. If material is not included in the article's Creative Commons licence and your intended use is not permitted by statutory regulation or exceeds the permitted use, you will need to obtain permission 
directly from the copyright holder. To view a copy of this licence, visit http://creativecommons.org/licen ses/by/4.0/.

\section{References}

Abdolmohammadi, M. J., Searfoss, D. G., \& Shanteau, J. (2004). An investigation of the attributes of top industry audit specialists. Behavioral Research in Accounting, 16(1), 1-17.

Agoglia, C. P., Brown, K. F., \& Hanno, D. M. (2003). Dickinson Technologies Inc: Assessing control environment and fraud risk. Issues in Accounting Education Teaching Notes, 18(1), 2-2.

Aldhizer, G. R., III, Miller, J. R., \& Moraglio, J. F. (1995). Common attributes of quality audits. Journal of Accountancy, 179(1), 61.

Alissa, W., Capkun, V., Jeanjean, T., \& Suca, N. (2014). An empirical investigation of the impact of audit and auditor characteristics on auditor performance. Accounting, Organizations and Society, 39(7), 495-510.

American Accounting Association Audit Section Education Committee. (2003). Challenges to audit education for the 21st Century: A survey of curricula, course content, and delivery methods. Issues in Accounting Education, 18(3), 241-263.

Arbolino, R., \& Boffardi, R. (2017). The impact of institutional quality and efficient cohesion investments on economic growth evidence from Italian regions. Sustainability, 9(8), 1432.

Arena, M., Arnaboldi, M., \& Azzone, G. (2006). Internal audit in Italian organizations. A multiple case study. Managerial Auditing Journal, 21(3), 275-292.

Arena, M., \& Azzone, G. (2007). Internal audit departments: Adoption and characteristics in Italian companies. International Journal of Auditing, 11(2), 91-114.

Australian Treasury. (2010). Audit quality in Australia: A strategic review. Canberra: Commonwealth of Australia: Australian Treasury.

Baker, C. R., Bédard, J., \& dit Hauret, C. P. (2014). The regulation of statutory auditing: an institutional theory approach. Managerial Auditing Journal, 29(5), 371-394.

Barney, J. (1991). Firm resources and sustained competitive advantage. Journal of management, 17(1), 99-120.

Beasley, M. S. (1996). An empirical analysis of the relation between the board of director composition and financial statement fraud. Accounting review, 71, 443-465.

Beaulieu, P. R. (2001). The effects of judgments of new clients' integrity upon risk judgments, audit evidence, and fees. Auditing: A Journal of Practice \& Theory, 20(2), 85-99.

Becker, G. S. (1993). Nobel lecture: The economic way of looking at behavior. Journal of political economy, 101(3), 385-409.

Bell, T. B., \& Carcello, J. V. (2000). A decision aid for assessing the likelihood of fraudulent financial reporting. Auditing: A Journal of Practice \& Theory, 19(1), 169-184.

Bernardi, R. A. (1994). Fraud detection: The effect of client integrity and competence and auditor cognitive style. Auditing, 13, 68 .

Bik, O., \& Hooghiemstra, R. (2016). The effect of national culture on auditor-in-charge involvement. Auditing A Journal of Practice \& Theory, 36(1), 1-19.

Bik, O., \& Hooghiemstra, R. (2017). Cultural differences in auditors' compliance with audit firm policy on fraud risk assessment procedures. Auditing: A Journal of Practice \& Theory, 37(4), 25-48.

Blouch, W. E., Ulrich, T. A., \& Michenzi, A. R. (2016). Effectiveness of auditing curricula revisted. Journal of Business and Accounting, 9(1), 37.

Bonner, S. E. (1990). Experience effects in auditing: The role of task-specific knowledge. The Accounting Review, 66, 72-92.

Bonner, S. E., \& Lewis, B. L. (1990). Determinants of auditor expertise. Journal of accounting research, $28,1-20$.

Bontis, N. (1998). Intellectual capital: an exploratory study that develops measures and models. Management Decision, 36(2), 63-76.

Boyle, D., \& Canning, M. (2005). The impact of audit education on perceptions of deficient auditor performance. Irish accounting review, 12(1), 15-37. 
Bröcheler, V., Maijoor, S., \& van Witteloostuijn, A. (2004). Auditor human capital and audit firm survival: The Dutch audit industry in 1930-1992. Accounting, Organizations and Society, 29(7), 627-646.

Cahan, S. F., Jeter, D. C., \& Naiker, V. (2011). Are all industry specialist auditors the same? Auditing: A Journal of Practice \& Theory, 30(4), 191-222.

Cahan, S. F., \& Sun, J. (2015). The effect of audit experience on audit fees and audit quality. Journal of Accounting, auditing \& finance, 30(1), 78-100.

Cameran, M., Ditillo, A., \& Pettinicchio, A. K. (2017). Audit team characteristics matter: how diversity affects audit quality. Europian Accounting Review, 17(4), 595-621.

Cameran, M., Ditillo, A., \& Pettinicchio, A. (2018). Audit team attributes matter: How diversity affects audit quality. European Accounting Review, 27(4), 595-621.

Cameran, M., Francis, J. R., Marra, A., \& Pettinicchio, A. (2013). Are there adverse consequences of mandatory auditor rotation? Evidence from the Italian experience. Auditing: A Journal of Practice \& Theory, 34(1), 1-24.

Cameran, M., Francis, J. R., Marra, A., \& Pettinicchio, A. (2015). Are there adverse consequences of mandatory auditor rotation? Evidence from the Italian experience. Auditing: A Journal of Practice \& Theory, 34(1), 1-24.

Carcello, J. V., Hermanson, R. H., \& McGrath, N. T. (1992). Audit quality attributes: The perceptions of audit partners, preparers, and financial statement users. Auditing, 11(1), 1.

Carcello, J. V., \& Neal, T. L. (2000). Audit committee composition and auditor reporting. The Accounting Review, 5(4), 453-467.

Chaffey, J., Van Peursem, K. A., \& Low, M. (2011). Audit education for future professionals: Perceptions of New Zealand auditors. Accounting Education:an International Journal, 20(2), 153-185.

Chang, H., Chen, J., Duh, R. R., \& Li, S. H. (2011). Productivity growth in the public accounting industry: The roles of information technology and human capital. Auditing: A Journal of Practice \& Theory, 30(1), 21-48.

Cheng, Y. S., Liu, Y. P., \& Chien, C. Y. (2009). The association between auditor quality and human capital. Managerial Auditing Journal, 24(6), 523-541.

Chow, C. W., Mcnamee, A. H., \& Plumlee, R. D. (1987). Practitioners perceptions of audit step difficulty and criticalness-implications for audit research. Auditing-a journal of practice \& theory, 6(2), $123-133$.

Cohen, J. R., \& Hanno, D. M. (2000). Auditors' consideration of corporate governance and management control philosophy in preplanning and planning judgments. Auditing: A Journal of Practice \& Theory, 19(2), 133-146.

Cohen, J., Krishnamoorthy, G., \& Wright, A. M. (2002). Corporate governance and the audit process. Contemporary accounting research, 19(4), 573-594.

Committee of Sponsoring Organizations of the Treadway Commission. (2013). Internal ControlIntegrated Framework: Internal Control Over External Financial Reporting: a Compendium of Approaches and Examples. Committee of Sponsoring Organizations of the Treadway Commission

Committee of Sponsoring Organizations of the Treadway Commission (COSO). (1992). Executive summary: Internal control: Integrated framework. New York: AICPA.

Cook, M. J. (1987). Two years of progress in financial accounting and reporting-February 1985 to January 1987. Journal of Accountancy, 163(6), 96-108.

Corbella, S., Florio, C., Gotti, G., \& Mastrolia, S. A. (2015). Audit firm rotation, audit fees and audit quality: The experience of Italian public companies. Journal of International Accounting, Auditing and Taxation, 25, 46-66.

Craswell, A. T., Francis, J. R., \& Taylor, S. L. (1995). Auditor brand name reputations and industry specializations. Journal of accounting and economics, 20(3), 297-322.

Daniele, V., \& Marani, U. (2011). Organized crime, the quality of local institutions and FDI in Italy: A panel data analysis. European Journal of Political Economy, 27(1), 132-142.

De Dominicis, L., Arbia, G., \& De Groot, H. L. (2013). Concentration of manufacturing and service sector activities in Italy: Accounting for spatial dependence and firm size distribution. Regional Studies, 47(3), 405-418.

DeAngelo, L. E. (1981). Auditor size and audit quality. Journal of accounting and economics, 3(3), 183-199.

Dechow, P. M., Sloan, R. G., \& Sweeney, A. P. (1995). Detecting earnings management. Accounting review, 70, 193-225. 
DeFond, M., \& Zhang, J. (2014). A review of archival auditing research. Journal of Accounting and Economics, 58(2-3), 275-326.

Del Monte, A., \& Papagni, E. (2007). The determinants of corruption in Italy: Regional panel data analysis. European Journal of Political Economy, 23(2), 379-396.

Delery, J. E. (1998). Issues of fit in strategic human resource management: Implications for research. Human Resource Management Review, 8(3), 289-309.

Delery, J. E., \& Doty, D. H. (1996). Modes of theorizing in strategic human resource management: Tests of universalistic, contingency, and configurational performance predictions. Academy of Management Journal, 39(4), 802-835.

Delery, J. E., \& Roumpi, D. (2017). Strategic human resource management, human capital and competitive advantage: is the field going in circles? Human Resource Management Journal, 27(1), 1-21.

DiMaggio, P. J., \& Powell, W. W. (1983). The iron cage revisited: Institutional isomorphism and collective rationality in organizational fields. American Sociological Review, 48, 147-160.

Doyle, J. T., Ge, W., \& McVay, S. (2007). Accruals quality and internal control over financial reporting. The Accounting Review, 82(5), 1141-1170.

Duska, R. (2005). The good auditor-Skeptic or Wealth accumulator? Ethical lessons learned from the Arthur Andersen debacle. Journal of Business Ethics, 57(1), 17-29.

Edgley, C., Sharma, N., \& Anderson-Gough, F. (2016). Diversity and professionalism in the Big Four firms: Expectation, celebration and weapon in the battle for talent. Critical Perspectives on Accounting, 35, 13-34.

Ge, W., \& McVay, S. (2005). The disclosure of material weaknesses in internal control after the Sarbanes-Oxley Act. Accounting Horizons, 19(3), 137-158.

Gómez-Guillamón, A. L. D., \& Sanchez-Val, M. M. (2012). The geographical factor in the determination of audit quality. Revista de Contabilidad, 15(2), 287-310.

Griffith, E. E., Hammersley, J. S., \& Kadous, K. (2015). Audits of complex estimates as verification of management numbers: How institutional pressures shape practice. Contemporary Accounting Research, 32(3), 833-863.

Haskins, M. E. (1987). Client control environments: An examination of auditors' perceptions. Accounting Review, 62, 542-563.

Hitt, M. A., Bierman, L., Shimizu, K., \& Kochhar, R. (2001). Direct and moderating effects of human capital on strategy and performance in professional service firms: A resource-based perspective. Academy of Management Journal, 44(1), 13-28.

Hope, O. K., Kang, T., Thomas, W., \& Yoo, Y. K. (2008). Culture and audit choice: a test of the secrecy hypothesis. Journal of Accounting and Public Policy, 27(5), 357-373.

Hossain, S., Yazawa, K., \& Monroe, G. S. (2017). The relationship between audit team composition, audit fees, and quality. Auditing: A Journal of Practice \& Theory, 36(3), 115-135.

Huang, R. D., \& Li, H. (2009). Does the market dole out collective punishment? an empirical analysis of industry, geography, and Arthur Andersen's reputation. Journal of Banking \& Finance, 33(7), 1255-1265.

Hunton, J. E., Hoitash, R., \& Thibodeau, J. C. (2011). Retracted: the relationship between perceived tone at the top and earnings quality. Contemporary Accounting Research, 28(4), 1190-1224.

International Auditing and Assurance Standards Board (IAASB). (2014). A Framework for Audit Quality: Key Elements that Create an Environment for Audit Quality. New York: IAASB.

Istituto Nazionale di Statistica (ISTAT) (2018), Il benessere equo e sostenibile in Italia (BES 2018), Available at https://www.istat.it/it/archivio/224669.

ISA Italia (2015), Principio di revisione Internazionale n. 315, "L'identificazione e la valutazione dei rischi di errori significativi mediante la comprensione dell'impresa e del contesto in cui opera", Effective in Italy for audits of financial statements for periods beginning on or after January 1, 2015 (Clarified version 2009). Available at https://www.revisionelegale.mef.gov.it/opencms/expor t/mef/resources/PDF/ISA_ITALIA_315_CL_10_12_14.pdf.

Jackson, A. B., Moldrich, M., \& Roebuck, P. (2008). Mandatory audit firm rotation and audit quality. Managerial Auditing Journal, 23(5), 420-437.

Kizirian, T. G., Mayhew, B. W., \& Sneathen, L. D., Jr. (2005). The impact of management integrity on audit planning and evidence. Auditing: A Journal of Practice \& Theory, 24(2), 49-67.

Knechel, W. R. (2000). Behavioral research in auditing and its impact on audit education. Issues in Accounting Education, 15(4), 695-712.

Kreutzfeldt, R. W., \& Wallace, W. A. (1990). Control Risk Assessments-Do they relate to errors. Auditing-A Journal of Practice \& Theory, 9, 1-26. 
Krishnan, J., \& Schauer, P. C. (2001). Differences in quality among audit firms. Journal of Accountancy, 192(1), 85.

La Rocca, M., La Rocca, T., \& Cariola, A. (2010). The influence of local institutional differences on the capital structure of SMEs: Evidence from Italy. International Small Business Journal, 28(3), 234-257.

Lai, S. M., \& Liu, C. L. (2018). The effect of auditor characteristics on the value of diversification. Auditing: a Journal of practice \& theory, 37(1), 115-137.

Lanzafame, M. (2009). Is regional growth in Italy endogenous? Regional Studies, 43(8), 1001-1013.

Larkin, J. M. (2000). The ability of internal auditors to identify ethical dilemmas. Journal of Business Ethics, 23(4), 401-409.

Lawrence, A., Minutti-Meza, M., \& Zhang, P. (2011). Can Big 4 versus non-Big 4 differences in audit-quality proxies be attributed to client characteristics? The Accounting Review, 86(1), 259-286.

Libby, R., \& Frederick, D. M. (1990). Experience and the ability to explain audit findings. Journal of Accounting Research, 28, 348-367.

Martin, B. C., McNally, J. J., \& Kay, M. J. (2013). Examining the formation of human capital in entrepreneurship: A meta-analysis of entrepreneurship education outcomes. Journal of Business Venturing, 28(2), 211-224.

Mazzocchi, M. (2008). Statistics for marketing and consumer research. Sage Publications.

McKnight, C. A., \& Wright, W. F. (2011). Characteristics of relatively high-performance auditors. Auditing: A Journal of practice \& theory, 30(1), 191-206.

Meyer, J. W., \& Rowan, B. (1977). Institutionalized organizations: Formal structure as myth and ceremony. American Journal of Sociology, 83(2), 340-363.

Meyer, K. E., \& Xin, K. R. (2017). Managing talent in emerging economy multinationals: Integrating strategic management and human resource management. The International Journal of Human Resource Management, 29(11), 1827-1855.

Moeckel, C. (1990). The effect of experience on auditors' memory errors. Journal of Accounting Research, 28, 368-387.

Morris, T., \& Empson, L. (1998). Organisation and expertise: An exploration of knowledge bases and the management of accounting and consulting firms. Accounting, Organizations and Society, 23(5-6), 609-624.

O’Donnell, E., \& Prather-Kinsey, J. (2010). Nationality and differences in auditor risk assessment: A research note with experimental evidence. Accounting, Organizations and Society, 35(5), 558-564.

O’Keefe, T. B., Simunic, D. A., \& Stein, M. T. (1994). The production of audit services: Evidence from a major public accounting firm. Journal of Accounting Research, 32(2), 241-261.

Patel, C., \& Psaros, J. (2000). Perceptions of external auditors' independence: some cross-cultural evidence. The British Accounting Review, 32(3), 311-338.

Pennings, J. M., Lee, K., \& Witteloostuijn, A. V. (1998). Human capital, social capital, and firm dissolution. Academy of Management Journal, 41(4), 425-440.

Pickerd, J. S., Summers, S. L., \& Wood, D. A. (2014). An examination of how entry-level staff auditors respond to tone at the top vis-à-vis tone at the bottom. Behavioral Research in Accounting, 27(1), 79-98.

Pittman, J. A., \& Fortin, S. (2004). Auditor choice and the cost of debt capital for newly public firms. Journal of accounting and economics, 37(1), 113-136.

Ployhart, R. E., \& Moliterno, T. P. (2011). Emergence of the human capital resource: A multilevel model. Academy of Management Review, 36(1), 127-150.

Public Company Accounting Oversight Board (PCAOB). (2013). Standing Advisory Group Meeting Discussion-Audit Quality Indicators. Washington: PCAOB.

Quadackers, L., Groot, T., \& Wright, A. (2014). Auditors' professional skepticism: Neutrality versus presumptive doubt. Contemporary accounting research, 31(3), 639-657.

Regoliosi, C., \& D'Eri, A. (2014). Good corporate governance and the quality of internal auditing departments in Italian listed firms. An exploratory investigation in Italian listed firms. Journal of Management and Governance, 18(3), 891-920.

Reynolds, J. K., \& Francis, J. R. (2000). Does size matter? The influence of large clients on office-level auditor reporting decisions. Journal of accounting and economics, 30(3), 375-400.

Samagaio, A., \& Rodrigues, R. (2016). Human capital and performance in young audit firms. Journal of Business Research, 69(11), 5354-5359. 
Sarens, G., \& Abdolmohammadi, M. J. (2011). Monitoring effects of the internal audit function: Agency theory versus other explanatory variables. International Journal of Auditing, 15(1), 1-20.

Sarens, G., \& Lamboglia, R. (2014). The (Mis)Fit Between The Profile Of Internal Auditors And The Internal Audit Activities". Accounting And Business Research, 44(1), 41-62.

Schelleman, C., \& Knechel, R. (2010). Short-term accruals and the pricing and production of audit services. Auditing: a journal of practices and theory, 29(1), 221-250.

Schmidt, R. N. (2014). The effects of auditors' accessibility to "tone at the top" knowledge on audit judgments. Behavioral Research in Accounting, 26(2), 73-96.

Simnett, R. (1996). The effect of information selection, information processing and task complexity on predictive accuracy of auditors. Accounting, Organizations and Society, 21, 699-717.

Sirois L. P., \& Simunic, D. A. (2011). Auditor size and audit quality revisited: The importance of audit technology. papers.ssrn.com.

Tie, R. (1999). Concerns over auditing quality complicate the future of accounting. Journal of Accountancy, $188(6), 14$.

UK Financial Reporting Council. (2008). The Audit Quality Framework. London: Financial Reporting Council (FRC).

Unger, J. M., Rauch, A., Frese, M., \& Rosenbusch, N. (2011). Human capital and entrepreneurial success: A meta-analytical review. Journal of Business Venturing, 26(3), 341-358.

Veltri, S., \& Silvestri, A. (2011). Direct and indirect effects of human capital on firm value: evidence from Italian companies. Journal of Human Resource Costing \& Accounting, 15(3), 232-254.

Von Nordenflycht, A. (2010). What is a professional service firm? Toward a theory and taxonomy of knowledge-intensive firms. Academy of Management Review, 35(1), 155-174.

Wang, Q., Wong, T. J., \& Xia, L. (2008). State ownership, the institutional environment, and audit choice: evidence from China. Journal of Accounting and Economics, 46(1), 112-134.

Wang, P., Yuan, L., \& Wu, J. (2017). The joint effects of social identity and institutional pressures on audit quality: The case of the Chinese Audit Industry. International Business Review, 26(4), $666-682$.

Weber, J., \& Willenborg, M. (2003). Do expert informational intermediaries add value? Evidence from auditors in microcap initial public offerings. Journal of Accounting Research, 41(4), 681-720.

Yan, H., \& Xie, S. (2016). How does auditors' work stress affect audit quality? Empirical evidence from the Chinese stock market. China Journal of Accounting Research, 9(4), 305-309.

Publisher's Note Springer Nature remains neutral with regard to jurisdictional claims in published maps and institutional affiliations.

Rita Lamboglia is Associate Professor of Corporate Governance and Accounting at the Parthenope University of Naples and Visiting Professor at the "Université Catholique de Lille". She received her Ph.D. in the same University and has been visiting fellow at "Université Catholique de Louvain" (UCL). Her research interests are on information systems, internal control systems and audit.

Daniela Mancini is Professor of Business Administration and Performance measurement and Business Analytics at the University of Teramo (Italy), where she is member of the Teaching Board of the Ph.D. in Economic and Social Sciences. She is Director of Master in Chief Financial Officer at Parthenope University of Naples. Her research areas are accounting and management information systems, management control, business networks, and non-financial Information. She is co-editor of Management Control journal, and International Journal of Digital Culture and Electronic Tourism, and member of the Editorial Board of The International Journal of Digital Accounting Research. 